\title{
Denique Onirocrites, sic erit Hippocrates: Dreams as a Diagnostic Tool in Early Modern British Medicine
}

\author{
By Steven Oberhelman *
}

\begin{abstract}
On 7 July 1663, a young Edward Browne, who later will become a famous ethnographer and court physician, presented his two theses for a baccalaureate degree at Cambridge University. The title of the first thesis was entitled Judicium de somniis est medico utile (A Determination [of Illness] Based on Dreams Is Useful for the Physician). In a long series of Latin elegiac couplets infused with language and imagery drawn from classical Roman poets like Virgil, Ovid, and Persius, Browne argues that the contents of a dream directly relate to the conditions of a patient's humors and that a wise person can diagnose the current state of an ailment on the basis of the dream's imagery. Browne relies on three main classical and Hellenistic Greek sources: Aristotle's works on dreams, Hippocrates' Regimen 4 (On Dreams), and Galen's On Diagnosis from Dreams. In this paper I discuss how Browne's theories derive from these ancient sources, especially Galen's text, which had appeared only two centuries earlier in the West in a Latin translation. More importantly I demonstrate how Browne's views were consistent with current medical theory prevalent throughout England and across Europe among physicians, philosophers, and laypeople.
\end{abstract}

Keywords: dreams, medicine in England, Galen, Edward Browne, Cambridge University, Artemidorus

\section{Introduction}

Edward Browne (1644-1708) was a physician and a traveler who wrote important accounts of his trips throughout Europe. He was the eldest of the eleven children of Sir Thomas Browne (1605-1682) and his wife Dorothy Mileham (1621-1685) at Norwich, then the largest city in England outside of London. ${ }^{1}$

Sir Thomas was himself a famous physician. ${ }^{2}$ He was educated at Pembroke College, and spent three years completing his medical education by studying at Montpelier, Rome, Padua, and Vienna with a final stay at Leyden, where he obtained a doctorate in medicine in 1633. On returning to England he wrote the first and most famous of his literary works, Religio Medici (The Religion of a Doctor), which was published in $1642{ }^{3}$ Sir Thomas practiced medicine from his

\footnotetext{
*Professor of Classics, Holder of the George Sumey Jr Endowed Professorship of Liberal Arts, and Associate Dean, Texas A\&M University, USA.

${ }^{1}$ Browne's life has rarely been treated by scholars and then only briefly. Short treatments are: Levental (1981) and Van Strien (2004).

${ }^{2}$ A brief introduction to Sir Thomas is Shaw (1978). Longer treatments are Huntley (1962), Nathanson (1967), Patrides (1982) and Post (1987).

${ }^{3}$ The book was a bestseller in its day and, as late as 1950, appeared on virtually every list of great books. This "religion of a doctor" has three themes. The first theme is tolerance. Sir Thomas believed that an individual's religious and philosophical beliefs ought to be respected, even if one disagreed with them, and, moreover, that the state should not impose, or interfere with, religious
} 
home. There he had a large laboratory for chemical experiments and studying natural history; his laboratory contained a famous collection of bird eggs and maps. Sir Thomas was also a polyglot, knowing six languages, and had an extensive library of Greek, Latin, Hebrew, French, Italian, German, Flemish, Dutch, and English texts, about 2,000 in all. Sir Thomas's library and his love of Latin no doubt influenced Edward for the rest of his life. ${ }^{4}$

Edward Browne attended grammar school in Norwich and was then admitted to Trinity College, Cambridge. In 1663, at the age of 21, he applied for admission to baccalaureate degree in medicine, stating that he had studied medicine for six years, had attended the usual lectures, had observed two dissections, and had engaged in the necessary disputations (Robb-Smith 1974, pp. 347-349). After taking his degree Browne began his continental education: six months in Paris, visiting the hospitals and attending lectures; to Montpellier and then to Italy, where he spent a few weeks studying anatomy at Padua; then north again retracing his steps, attending further courses at Paris, where he caught smallpox; and finally in the late summer of 1665 was home again at Norwich. ${ }^{5}$ Browne next enrolled at Merton College, Oxford, on 19 June 1666, and on 4 July 1667 received his doctorate in medicine. Since he had decided on a medical career in London, it was necessary for him to join the College of Physicians, and on 16 March 1668 he was accepted as a candidate.

However, Browne did not wish to begin a medical practice immediately, and persuaded his father to allow him to make another foreign journey. From August 1668 until Christmas 1669 he visited the Low Countries, Germany, Austria, Hungary, Serbia, Bulgaria, and northern Greece, where at Larissa he met the sultan of the Ottoman Empire. Upon his return, Browne published an account of the countries through which he had passed. He had earlier become a fellow of the Royal Society on 2 January 1668, and while abroad he sent to its secretary, Henry Oldenburg, information on the gold, silver, and copper mines in Hungary,

practices. When Religio Medici appeared, it was one of the earliest Western statements of respect for religious beliefs that are different from one's own. The second theme is a close connection between religion, and science or medicine. Sir Thomas believed that by using reason and observation a physician could strengthen his faith in God. Rather than simply follow church authority or biblical teachings, Sir Thomas argued that scientific training and reason enabled one to find God. The third theme is the moral responsibility of the doctor. Sir Thomas believed that the practice of medicine should be the reflection of a moral life, not simply a profession or business. Thus, service to others is one of the highest purposes of a physician. One should not charge a fee when one is unable to help a patient, and the physician should remember that his patient's best interests always take priority over his own. This long note is not superfluous but is intended to point out the relevance of Religio Medici today: Sir Thomas argued for a tolerant world, a place where science, nature, and faith can be discussed with understanding and without patriotic chauvinism and cultural arrogance. His willingness to discuss religious and scientific matters rationally, and his tolerance of other cultures and religions, in a time when persecution and holy wars were all too common, is praiseworthy.

${ }^{4}$ Finch (1986, p. 93): Sir Thomas told Edward to read Latin poets for "their handsome expressions and sense," and also Aristotle (pp. 101, 104). Edward certainly knew his Aristotle as we will see later in this paper, although I would note that Aristotle was predominant in the university curriculum (Costello 1958, p. 9).

${ }^{5}$ For the reason why graduates went to the Continent for completing their medical training see Allen (1946, pp. 121, 130). Also, Allen (1946, pp. 130-131). 
Transylvania, and Austria. But soon it was time for Browne to settle down to serious work. On 14 June 1675 he was chosen lecturer at Surgeons' Hall, and on 29 July 1675 he became a fellow of the College of Physicians, of which he eventually served as treasurer (1694-1704) and president (1704-1708). Browne had a large and lucrative medical practice, with many aristocratic patients, including King Charles II. On 7 September 1682 Browne became permanent physician to St Bartholomew's Hospital.

Browne produced two translations: A History of the Cossacks, ${ }^{6}$ and the lives of Themistocles and Sertorius for inclusion in John Dryden's Plutarch's Lives (1683-1686). He is best known, though, for his travel books detailing trips to Hungary, Serbia, Bulgaria, Macedonia, Thessaly, and Austria. ${ }^{7}$ An account of his journeys through the Low Countries and Germany appeared in 1677, an updated and heavily illustrated edition in 1685 , and a reprint edition in $1687 .{ }^{8}$

Browne died, after a short illness, on 28 August 1708, in his country house at Northfleet in Kent. A Latin inscription on the memorial stone over his grave in the local church pays tribute to him as a famous doctor physician and the author of travel books.

\section{Browne's Thesis on Dreams on Medicine}

Of Browne's writings one is the focus of this article: his first thesis or proposition delivered on Commencement Day, 7 July 1663, to partially fulfill the requirements for the baccalaureate degree in medicine. To earn the degree in seventeenth-century England, a student was required to study six years, attend two dissections, pass an examination, and participate in two disputations. ${ }^{9}$

\footnotetext{
${ }^{6}$ A Discourse of the Original, Countrey, Manners, Government and Religion of the Cossacks, with another of the Precopian Tartars. And the History of the Wars of the Cossacks against Poland (London: T. N. for Hobart Kemp, 1672); this was a translation of Pierre Chevalier's Histoire de la guerre des Cosaques contre la Pologne (Paris: Thomas Iolly, 1668).

${ }^{7}$ A Brief Account of some Travels in Hungaria, Servia, Bulgaria, Macedonia, Thessaly, Austria, Styria, Carinthia, Carniola and Friuli. As also some observations on the gold, silver, copper, quicksilver, mines . . . in those parts, etc. (London: T. R. for Benj. Tooke, 1673).

${ }^{8}$ A Brief Account of some Travels in divers parts of Europe, viz. Hungaria, Servia, Bulgaria, Macedonia, Thessaly, Austria, Styria, Carinthia, Carniola, and Friuli. Through a great part of Germany, and the Low-Countries ... With some observations on the gold, silver, copper, quicksilver mines ... in those parts ... The second edition, with many additions (London: T. R. For Benj. Tooke, 1687).

${ }^{9}$ The Elizabethan Statue of 1570, De legibus baccalaureis, cap. xv, states: "Medicinae studiosus sex annos rem medicam discet ejus lectionis auditor assiduous: anatomias duas videat: bis respondeat, semel opponat antequam baccalaureus fiat" ("The one pursuing medicine will study medicine for six years and be an eager listener to what is being read; he should watch two dissections; he should serve as a respondent twice, at the same time as serving as an opponent twice; if so, he can receive his baccalaureate"). Allen (1946, p. 122) writes that the lecturer in medicine had to read Galen and Hippocrates and the Regius Professor lectured four days a week, with absences subject to fines (hence the "be an eager listener" above). All translations in this article are my own, unless otherwise noted.
} 
Disputations were an elaborate affair and had set ceremonial rules (Costello 1958). ${ }^{10}$ On Commencement Day (in die comitiorum), the baccalaureate candidate appeared before mentors and faculty to defend two propositions. ${ }^{11}$ The propositions were written in Latin hexameters or elegiac distiches, printed on the same side of the broadside. ${ }^{12}$ The writer was required to use Virgilian diction and to refer to Latin poets like Ovid and Persius (Costello 1958, pp. 17-19). ${ }^{13}$ Three sophisters (advanced undergraduates) had previously been selected to act as opponents; their job was to refute the proposition with syllogisms and other arguments. ${ }^{14} \mathrm{~A}$ moderator opened the event with an introductory speech, followed by words from the "Fathers" (that is, the responder's academic advisers). The broadside was distributed to everyone in attendance and then the candidate delivered in Latin the first proposition. The sophisters, each in succession, attempted to refute (also in Latin) the thesis; when each sophister had finished, the responder offered a rebuttal. A total of 30 minutes was allotted for the reading, oppositions, and defense. The second proposition was then presented and the same procedure as before was implemented. As stated above, a baccalaureate candidate, to be approved for graduation, not only had to act as responder for his own propositions, but to have served as sophister twice. ${ }^{15}$ For the doctorate in medicine a student needed to study for five more years, attend three dissections, pass two more examinations, and undergo two more disputations. The actual license to practice was not granted until the student had successfully cured three patients. ${ }^{16}$

Browne first matriculated at Trinity College, Cambridge, in 1657, and in July of 1663 presented himself for the baccalaureate in medicine. Since he had attended Trinity College for six years, had observed two dissections, and had acted as sophister, all that remained were the defense of his responsions or propositions. On 7 July, Browne offered his first thesis: Judicium de somniis est Medico utile ("A Determination [of Illness] Based on Dreams Is Useful for a Physician"). The text, written in elegiac distiches and in good classical Latin diction, has been preserved. A copy resides in the British Library (shelfmark 11409.i.10.[6]). ${ }^{17}$ The subscript

\footnotetext{
${ }^{10}$ Costello (1958, pp. 8-10) observes disputations had their origin in medieval scholasticism.

${ }^{11}$ For examples of the types of undergraduate disputation topics, see Allen (1946, p. 124).

${ }^{12}$ John Milton, the renowned poet, wrote in 1628 on Naturam non pati senium ("That nature is not subject to old age") and De idea platonica quemadmodum Aristotelis intellexit ("On the Platonic idea as Aristotle comprehended"). Milton, it should be noted, wrote Latin verses for other students (Costello 1958, pp. 17-18).

${ }^{13}$ Twigg (1990, p. 207 (bibliography in note 3)) observes that students knew Latin grammar even before entering the university and continued to study it and Greek as an undergraduate.

${ }^{14}$ As stated above, an undergraduate had to serve twice in this role to fulfill their baccalaureate requirements. For how the sophisters were selected see Evans (2009, pp. 249-250).

${ }^{15}$ The Elizabethan Statues of 1570 dictated the medical school at Cambridge. See the discussion in Anderson (2004, pp. 11-13).

${ }^{16}$ Elizabethan Statues, De baccalaureis medicinae, cap. xvii-xviii. Also, Robb-Smith (1974, pp. 328-329). Medical education remained stagnant for over three centuries and played a large role in the low number of doctors being produced annually by Cambridge and Oxford every year. It is estimated that between the years 1500 and 1856, only 3,000 physicians came from those two universities, that is, only eight or nine every year. See Rook (1963, pp. 639-643, esp. p. 643). Cf. Robb-Smith (1974, p. 359).

${ }^{17}$ The broadside is available at the General Reference Collection desk. My thanks of appreciation to the staff of the British Library for assistance.
} 
reads: Julii 7. 1663. In die Comitiorum, Refpondente $M^{\text {ro }}$ Brown, Bacc. Med. Coll. Trin. ("July 7, 1663. On Commencement Day, Mr. Brown[e] acting as responder. For the baccalaureate in medicine, Trinity College").

For our purposes here I omit the opening remarks and move to the section in which Browne argues that dream imagery can portray disease in a dreamer's body. A literal translation follows.

Qui jacet, ille fuum poterit fentire dolorem,

Atque fibi Hippocrates hactenus alter erit,

Ille fuos Manes patitur per fomnia, dum mens

Cogitur ufque fuis invigilare malis.

Somnia quae versos aequant imitamine morbos

Sollicitum vexant nocte ruente caput:

Arida dum miferos febris depafcitur artus,

Et jecur, Aetnaeo non minor, ignis edit,

Somniat Empedoclem femet ductâfle, videtur

Torridus Aetneas ire redire vias.

Aut Phaetontaeos credens fe fcandere currus,

Per calidum ignivomos aethera flectit equos:

Vitrea fi calido tumeat fub pectore bilis,

Fervidus \& Cholerae bulliat igne finus,

Hoftes, arma crepat, per Amica filentia noctis,

Atque ipfos fomnos irrequietus agit:

Humorum vario cerebrum quàm fluctuat aeftu?

Frigida cùm nimium vifcera Phlegma gelat,

Stagna, lacus, amnes, \& latum profpicit aequor

Anxius, inque vado naufragus horret aquas;

Quámque femel tantùm poterit tranare paludem,

Saepiùs horrendam fe putat ire viam:

ERGO,

Artemidore tuas Medicus pervolvere chartas

Difcat, \& ufque tuum dextra fatiget opus;

Unus fic meritò viciffe Machaonas omnes,

Parcarum \& poterit fiftere fila trium,

Flectere fic folitum curfum irremeabilis undae;

Denique Onirocrites, fic erit Hippocrates.

The sick person who lies ill will be able to sense his own affliction,

And in this way he will be a second Hippocrates unto himself:

He suffers his fate through dreams, while his mind

Is forced to stay wakeful incessantly because of ills.

Dreams which are comparable to actual illnesses by resemblance

Plague the disturbed mind when night falls:

While a dry fever wastes his ailing limbs,

And a fire no less than Etna itself consumes the liver,

One dreams that Empedocles has led him by the hand, and he seems,

All parched, to be traversing to and fro the pathways of Etna.

Or, believing he has climbed into the chariot of Phaethon,

He directs the fire-spewing horses across the hot air of heaven:

If vitreous bile swells beneath his feverish breast, 
And his bosom boils fiery-hot with the fire of cholera,

Enemies and weapons resound throughout the benign stillness of the night,

And restlessness disturbs his sleep:

How in the heat of a fever the intellect is shaken by the undulating change of the humors!

When cold phlegm causes an excessive congealing of the internal organs,

Swamps, lakes, streams, and the broad sea are beheld by the distressed [mind],

And as a shipwrecked man one shudders at the waters on the shoals;

On one occasion he will be able to swim across a swamp,

But more often he imagines that he is travelling on a terror-filled journey.

Therefore,

May the physician, Artemidorus, learn to turn over your pages

And may his right hand ever wear out your work;

In this way he alone will deservedly have surpassed all the practitioners of the Machaonian craft,

And be able to arrest the threads of life spun by the three sisters

And thus turn the usual course of the stream from which one cannot return.

In a word, the dream interpreter will thus be Hippocrates.

\section{Browne's Debt to Classical Greek and Latin Sources}

This text is interesting. First, Browne has borrowed heavily from Golden Age and Silver Age Latin poets for phraseology and exempla. This is not unexpected, though, as any candidate would have been proficient in Latin and classical training since childhood. I will not delve into the literary aspects of Browne's thesis because of space considerations. But a few examples will suffice to illustrate Browne's mastery of Latin poets.

Browne, line 12: cogitur usque suis invigilare malis

Virgil, Aeneid 6.743: quisque suos patimur manis mens invigilare malis

Ovid, Fasti 4.530: capiat somnos invigiletque malis

Silius Italicus, Punic Wars 10.330-331: sed mens invigilat curis ${ }^{18}$ noctisque quietem / ferre nequit

Browne, line 15: arida dum miseros febris depascitur artus Virgil, Georgics 3.458: cum furit atque artus depascitur arida febris

Browne, line 28: anxius, inque vado naufragus horret aquas

Ovid, Letters from the Black Sea 2.7.8: tranquillas etiam naufragus horret aquas ${ }^{19}$

Browne's text is far more interesting for its clear discussion of how dreams can function as a diagnostic tool in medicine. For his ideas Browne has drawn from contemporary humoral theory (based on Greek and Roman medicine) and from ancient philosophers and medical writers. He also reflects the then current

\footnotetext{
${ }^{18}$ Here the word curae ("anxieties") is a synonym for Browne's mala ("evils").

${ }^{19}$ The words in both texts conclude the second of an elegiac couplet.
} 
theories held by authors in England and on the European continent regarding the prognosticative and diagnostic ability of dreams.

The notion that a person's four humors - black bile, phlegm, yellow bile, and blood-determined the workings and wellbeing of a person's body was pervasive throughout early modern England. Literary writers like Shakespeare, philosophers like Thomas Hobbes (1588-1679), lay dream interpreters like Thomas Hill (1528d. unknown), and popular writers like Richard Haydock (1569-1642), all commented how the humors can affect a person's moods, emotions, and actions, and how external factors like food, weather, and climate can upset the equilibrium of the humors. ${ }^{20}$ Moreover, each humor had its own associations with times of year, emotions, the elements, and a person's lifetime: blood is characterized by spring, passion, air, and childhood; yellow bile, by summer, anger, fire, and youth; black bile, by autumn, introspection, earth, and adulthood; and phlegm, by winter, melancholy, water, and old age. ${ }^{21}$ It was also thought that personality types and traits were based on one's humors. Galen, the second-century CE physician, wrote in his De temperamentis (Concerning the temperaments) that there are nine temperaments, when one takes into account the possible combinations of the four humors, the four elements (earth, air, fire, water), and the four qualities (wet, dry, hot, cold). The well-balanced person had the proper and equal proportions of humors and qualities. ${ }^{22}$

Four temperaments were singled out on the basis of the humors: sanguine, choleric, melancholic, and phlegmatic. But each temperament could become dominant from an excess of a specific humor, and so the resulting imbalance could cause a temporary or long-term change in personality. Let us take yellow bile as an example. Yellow bile, being dry and hot, is easily susceptible to heat. Thus, a fever, which is a hot and dry disease, is reflective of an excess of yellow bile, and steps need to be undertaken to restore the proper balance of yellow bile in the body. $^{23}$

It had long been established in Greek and Roman medicine, philosophy, and science that dreams may contain images that indicate the lack or excess of humors in the dreamer's body. ${ }^{24}$ Hippocrates $^{25}$ viewed medical dreams as non-divine dreams (as opposed to divine dreams that prognosticate future events). The medical dream, which describes both the physical state of the body and the regimen needed to restore health, occurs when the soul, while the body is asleep, performs through its own agency all the acts of the body, such as sight, touch, perception of pain, and reflection (Oberhelman 1993a). During the body's sleep, a displacement of perception takes place: the soul's cognitive and sensory processes

\footnotetext{
${ }^{20}$ See chap. 1 of Rivière (2013) and Rivière (2017), chap. 1: 'Seasons of Sleep': Natural Dreams, Health, and the Physiology of Sleep, pp. 17-49.

${ }^{21}$ This all goes back to the Hippocratic corpus. See Jouanna and Allies (2012).

${ }^{22}$ For Galen's theories and their impact on early modern European thought, see Stelmack and Stalikas (1991).

${ }^{23}$ This theory lasted from the Middle Ages through the eighteenth century (Siraisi 1990).

${ }^{24}$ See Hulskamp (2013), for a thorough review. Also, Oberhelman (1993), Teilband II, 37, 2, pp. 121-156.

${ }^{25}$ I use the term "Hippocrates" to denote the many writers who wrote the texts that make up the Hippocratic corpus.
} 
shift inwardly, to the body, whereby the soul perceives the conditions of the body, including diseases. These perceptions constitute the dream's images and offer information on the dreamer's state of health. ${ }^{26}$

The author of the Hippocratic Regimen combined a physiological and a hermeneutic approach to the dream, seeing significance not only in the dream event but also in its contents; thus dreams can have a dual purpose, medical diagnosis (what is happening to the body) and medical prognosis (what is going to happen to the body) (see Hulskamp 2015, Van der Eijk 2004). A medical dream, for the Hippocratic author of Regimen, was analyzed according to a microcosmmacrocosm analogy. The human body is the microcosm of the universe (the macrocosm) and so the circulations in the outer, middle, and hollow parts of the body are analogous to the outer, middle, and hollow circuits (the stars, sun, and moon). ${ }^{27}$ Thus, according to this model of analogy, if someone dreams of a star (outer circuit) disappearing or suffering some sort of harm, this means that a moist and phlegm-like secretion has fallen to the body's outer circulation; the dreamer must then undergo a medical regimen to remove the excess moisture from the body, for example, by inducing perspiration. Dream images involving terrestrial phenomena are analogous to parts of the human body. For example, the earth is analogous to the dreamer's skin; a tree, to the penis; cisterns, to the bladder; rivers, to the blood's circulation and quantity. Thus, a dream of seeing the earth flooded with water indicates that the body is excessively moist, and the patient must take steps to promote drying. The most common regimens to counter-act imbalances in the body were vapor baths, drying and cooling, alterations in a patient's food and drink, emetics, hellebore, and conducting exercises or avoiding them.

Aristotle believed that dreams are merely accidental products of the imagination which occur during sleep. ${ }^{28}$ Dreams do not involve actually sensing a stimulus because during sleep the senses do not work as they normally do while one is awake. In sleep, sensation is still involved, but in a different way than during the waking-state. During the day, when a person perceives a stimulus and the stimulus is no longer the focus of his attention, it leaves behind an impression. When the body is awake, a person constantly encounters new stimuli that are sensed and so the impressions left from previously perceived stimuli are ignored. However, during sleep, the impressions created by stimuli throughout the day now become noticed because there are no new sensory experiences to distract the faculty of perception. Aristotle argues that in the center of the heart the impressions occur as images and these images constitute our dreams. But since the images portray only the impressions and not the actual stimuli, dreams only resemble the experience that occurred when awake.

Aristotle applies this theory of dreams to medicine (see Van der Eijk 1995). As I said, stimuli, especially those arising from the body, escape our attention during the waking-state because the waking movements and outside sense perceptions are too great. But in sleep, the opposite occurs: small movements from

\footnotetext{
${ }^{26}$ Full discussion in Hulskamp (2008).

${ }^{27} \mathrm{~A}$ fuller discussion on Hippocrates in this respect is Hulskamp (2013).

${ }^{28}$ For a discussion of Aristotle's views, see, inter alios (Segev 2012); text and commentary in Gallop (1990).
} 
within the body are greater and therefore are perceived. Thus, diseases may be detected in dreams because their stimuli will dominate the weaker external perceptions. A dream therefore can be useful for a physician or any other wise person since it may come from internal sensations of disease.

The second-century CE Rufus insisted that a physician should take into account a patient's dreams: "And you should also ask ... whether the patient has had any vision or dreams, since from these a doctor can also make his inferences" (see Rufus 2001, p. 398, Oberhelman 1993b, § II), The images of the dream are to be applied to the humors of the body on the basis of the microcosm-macrocosm analogy. Rufus gives three illustrative dreams, each of which he interprets along the methodology in the Hippocratic Regimen. A wrestler dreamt that he spent the night in a black marsh of fresh water; the dream indicated the need of a massive evacuation of blood. A feverish patient dreamt of violence and fighting; this meant that he needed to be bled. Another patient, who had excessive moisture in his body, dreamt of swimming in a river.

Dreams exerted considerable influence on the life of Galen (Holowchak 2001, chap. 3 (with Appendices B and C)). Galen's thoughts are outlined in his a short treatise entitled On Diagnosis from Dreams. ${ }^{29}$ In the text Galen adduces four sources for dreams. Some images are daytime thoughts that reappear in a dream; this occurs most frequently when a person is overly concerned or anxious. Other images merely reproduce what one habitually does in the daytime; thus, a baker will dream of making bread, a sailor will dream of sailing, and an artist will have dreams pertaining to the arts. Dreams also arise when the soul, through its inherent power, foretells future events - a theory that the Stoics had developed. Finally, dreams can give a clue to the dreamer's medical condition by portraying in symbolic images the state of the humors in the body.

Galen's views on medical dreams derive from Aristotle and the Hippocratic Regimen. While the body is asleep, the soul sinks into the interior of the body and is there removed from outside sensory perceptions. The soul then forms images from residues of waking-state thoughts and through its own prognosticative ability; it also receives images from the various parts of the body. All these images are influenced by the dreamer's physical condition and the balances of the four bodily humors.

Galen used various methods of interpretation, but the one most preferred was the Hippocratic microcosm-macrocosm analogy. ${ }^{30}$ Galen refined this system by also taking into account the symbolic similarity between dream images and the various mixtures of the humors and elements. Thus, if someone dreams of snow or ice, he is ill from an excess of phlegm, since this humor is cold and wet. A dream of deep darkness means disease from black bile, for this humor is dry and cold. A fire in a dream indicates yellow bile, as this humor is hot and dry like fire. As per the Regimen's microcosm-macrocosm analogy, excess blood in the body will cause an image of standing in a cistern of blood; a fever on the verge of crisis, an image of swimming or bathing in hot water; too much sperm, an image of sexual intercourse; a large quantity of feces or foul humors, an image of sitting amidst

\footnotetext{
${ }^{29}$ Text is in Guidorizzi (1973).

${ }^{30}$ See Hulskamp (2013) for a thorough discussion.
} 
filth and dung; a plethora of humors, the impression that one is carrying a heavy burden or is scarcely able to move.

Browne replicates these same ideas in his thesis. ${ }^{31}$ In lines $13-14$ he restates Hippocrates' and Aristotle's theories that at night the mind is besieged by images that reflect a person's illness and that these images resemble the diseases afflicting the body:

Somnia quae versos aequant imitamine morbos

Sollicitum vexant nocte ruente caput:

Dreams which are comparable to actual illnesses by resemblance

Plague the disturbed mind when night falls:

In other words, an illness is presented to the mind through imagery and resemblances, and by examining the images the astute person can understand the medical event underlying the image. ${ }^{32}$ What Browne is doing here is to give us Aristotle's method of interpreting dream imagery. Aristotle wrote that the best interpreter of dreams was the one able to observe resemblances. Dream images are like reflections in water: the water's motion, to the degree that the water is rough, will distort the original. It is up to a skillful interpreter to recover the original from the reflection. Browne is arguing that dreams caused by an illness are not exactly replicated in the imagery. There is a dream language and it uses metaphors. The wise person can take the metaphorical image and translate it back into the real, original meaning. Dream content is not always literal; rather, it is represented through resemblances.

Browne spends much of his thesis dealing with the excess of yellow bile as manifested in images that reflect inflammation of the liver and a high fever. $\mathrm{He}$ begins with a long series of images of excessive fire and heat:

Arida dum miferos febris depafcitur artus,

Et jecur, Aetnaeo non minor, ignis edit,

Somniat Empedoclem femet ductâfle, videtur

Torridus Aetneas ire redire vias.

Aut Phaetontaeos credens fe fcandere currus,

Per calidum ignivomos aethera flectit equos:

While a dry fever wastes his ailing limbs,

And a fire no less than Etna itself consumes the liver,

\footnotetext{
${ }^{31}$ Sir Thomas Browne in Religio Medici writes that young doctors should read Galen and Hippocrates and in the original; otherwise they could not be great physicians. Allen (1946, pp. $131,124)$ observes that the curriculum at British medical schools was conservative at this time and stressed the writings of Galen and Hippocrates. For a thorough discussion of the theory of the humors and medical dreams during the time period of Browne, see Rivière (2017, chapter 1: 'Seasons of Sleep': Natural Dreams, Health, and the Physiology of Sleep, esp. pp. 17-49). Cf. Siraisi (2015), on the medical theory of dreams as they relate to the humors and temperaments; and Scott (2014, pp. 174-176).

${ }^{32}$ The phrase somnia . . . imitamine is in fact borrowed from Ovid's Metamorphoses 11.626: somnia, quae veras aequent imitamine formas ("Dreams which replicate appearances through imitation of the real"). I owe the translation of Ovid to Scioli (2015, p. 71).
} 
One dreams that Empedocles has led him by the hand, and he seems,

All parched, to be traversing to and fro the pathways of Etna.

Or, believing he has climbed into the chariot of Phaethon,

He directs the fire-spewing horses across the hot air of heaven:

Browne's views reflect Hippocrates in Regimen 4.89: "If [heavenly bodies in a dream] appear to be fiery and hot, a secretion of bile is indicated." And Galen: "Someone dreaming of a conflagration is troubled by yellow bile" and "[S]ome who are about to sweat critically seem to be bathing and swimming in receptacles of hot water.",33

Browne proceeds to describe combat against enemies as a sign of excessive bile (lines 23-24):

Hoftes, arma crepat, per Amica filentia noctis,

Atque ipfos fomnos irrequietus agit:

Enemies and weapons resound throughout the benign stillness of the night,

And restlessness disturbs his sleep:

Rufus of Ephesus also wrote that dreaming of violence and fighting symbolizes a fever that must be bled (Oberhelman 1993b, p. 138, with note 73, referencing Hippocrates, Regimen 4.88 and 4.93).

Browne switches humors in lines 26-30-from yellow bile to cold phlegm. Images of bodies of water, swimming in pools, being swept by ocean waves all reflect excessive moisture (lines 26-30):

Frigida cùm nimium vifcera Phlegma gelat,

Stagna, lacus, amnes, \& latum profpicit aequor

Anxius, inque vado naufragus horret aquas;

Quámque femel tantùm poterit tranare paludem,

Saepiùs horrendam fe putat ire viam:

When cold phlegm causes an excessive congealing of the internal organs,

Swamps, lakes, streams, and the broad sea are beheld by the distressed [mind],

And as a shipwrecked man one shudders at the waters on the shoals;

On one occasion he will be able to swim across a swamp,

But more often he imagines that he is travelling on a terror-filled journey.

So too Hippocrates, Regimen 90:

Springs and cisterns indicate some trouble of the bladder; it should be thoroughly purged by diuretics. A troubled sea indicates disease of the belly; it should be thoroughly purged by light, soft aperients. . . . To see the earth flooded by water or sea signifies a disease, as there is much moisture in the body. What is necessary is to take emetics, to avoid luncheon, to exercise and to adopt a dry diet. Then there should be a gradual increase of food, little by little, and little to begin with. ... If the dreamer thinks that he is diving in a lake, in the sea, or in a river, it is not a good sign, for it

\footnotetext{
${ }^{33}$ It would have been easy for Browne to know the Hippocratic and Galenic treatises on dreams since they were published together starting c. 1500; see Siraisi (2015, p. 312, note 39).
} 
indicates excess of moisture. In this case also benefit comes from a drying regimen and increased exercises.

Rufus of Ephesus writes in a similar way: “A wrestler's dream of spending a night in a black marsh of fresh water indicates the need for a massive evacuation of blood . . . and a dream of swimming in rivers means excessive moisture in the body" (Oberhelman 1993b, p. 138). Galen agrees: "A rainstorm indicates that cold moisture abounds; snow, ice, and hail, indicate cold phlegm. . . A wrestler who seemed to be standing in a receptacle of blood and to keep above it with difficulty had an abundance of blood and was in need of purging." 34

\section{Browne and Current English and Continental Theories}

Browne's theories and examples may not necessarily be derived from Greek and Roman sources, for they were common at the time. Thomas Hill, whose Moste Pleasaunted Arte of the Interpretation of Dreams was published in 1576, distinguished dreams caused by excesses of the humors from other dreams. He writes (p. 38) that dreams "signifye euill, when the spirites and heate renewed in the sleepe transpose them vpon those euill humors, whiche before rested, for asmuch as then through these the lyke vapours be eleuated and stirred vppe, and these by their ill nature, cause men to feare" (see Hodgkin 2007, p. 112 with note 10). Levinus Lemnius (1505-1568), whose work in Dutch was translated into English by Thomas Newton (1542?-1607), ${ }^{35}$ also wrote that the humors determine the health or sickness of the body and that dreams portray the dominant humor through certain images. Thus, a dream of "dvuinge ouer head and eares in Water, or to be in Bathes \& Raynes" shows an excess of phlegm, as will "hayle. Snow, Yse, storme." David Person (exact dates unknown), in his Varieties: Or, a Surveigh of Rare and Excellent matters (1635), states that a dream's images reflect a person's dominant humor. So, the choleric person will dream of fire and wars, while the phlegmatic person will see such images as waters and drowning. Person writes (pp. 251-252): "As for Cholericke, who dreameth of fire, debates, skirmishes and the like ... the flegmaticke dreameth of waters, seas, drowning, and the rest." Thomas Tryon in 1691 wrote: "Physitians generally agree, that the natural temperament or complexion, and consequently many times the secret Diseases of persons are as soon, or better found out by their Dreams, than by any outward signs" (Tyron 1691, pp. 5-6). ${ }^{36}$

\footnotetext{
${ }^{34}$ Translations of Galen are drawn from Oberhelman (1983, pp. 36-47).

${ }^{35}$ The original work was in Latin and entitled De habitu et constitutione corporis. The translation is: The touchstone of complexions generallye appliable, expedient and profitable for all such, as be desirous \& carefull of their bodylye health: contayning most easie rules \& ready tokens, whereby euery one may perfectly try, and throughly know, as well the exacte state, habite, disposition, and constitution, of his owne body outwardly: as also the inclinations, affections, motions, \& desires of his mynd inwardly / first written in Latine, by Leuine Lemnie ; and now Englished by Thomas Newton (London: Thomas Marsh, 1576).

${ }^{36}$ See Wiseman et al., pp. 3-4. See also the excellent discussion of Haydock (2008, pp. 24-26, 4)1; Levin (2008, pp. 42-45) also discusses, the humoral medical dreams by Thomas Nashe (1567-
} 
Views on the imbalances in the humors as a cause of dreams were a mainstay of continental philosophy and medicine as well. Nearly a century before Browne, Gerolamo Cardano (1501-1576) published the most significant Renaissance discussion on dreams in his commentary, Synesiorum Somniorum omnis generis insomnia explicantes, libri IV (Four Books in which every type of dream in Synesius' 'On dreams' is explained) (Basel, 1562). Cardano argued that dreams may derive from the bodily humors and thus predict states of health. Like Hippocrates and Galen, Cardano points out that dream images should be interpreted through correspondences of the microcosm of the body and the macrocosm of the university (Synesiorum Somniorum, 1.1-15). The dream, when properly interpreted, may diagnose the body's condition. Cardano, although a physician, did not apparently interpret medical dreams except his own; he only records dreams that he had heard from other doctors (Siraisi 2015, chapter 5, especially pp. 181-182). Since Carlano had a great disdain for popular dream interpreters, this may explain his aversion to interpreting others' dreams and on his insistence on self-diagnosis.

Francisco Sanches (1550-1623), like Cardano a doctor and philosopher, in his commentary on Aristotle's On divination (Commentarii de divination per somnum, ad Aristotelem ${ }^{37}$ ) follows very closely Aristotle's and Hippocrates' views. Sanches writes that after the soul withdraws into the inner part, it becomes aware of both external and internal objects and sensations. In particular, the soul sees "every condition of the body" (omnem corporis statum). Any imbalance in the humors will then be manifested through relevant imagery:

Denique omnem corporis ftatum videt, aut fimpliciter \& explicitè, aut fub variâ fomniorum fpecie. Ut cùm multa defluit pituita fomniat fe imbre largo perfundi, aut per fluvios \& acquofa loca ferè fuffocari . . . Cùm dominator melancholicus humor, fomniat cadaver, neces, vulnera, ferpentes, cruces, luctus, \& omnia maefta. Cùm fanguis, nuptias, choreas, convivial, rifus, \& omnia laeta; cùm bvilis, rixas, ignes, incendia, corufcationes (p. 288).

Thus [the soul] sees every status of the body, either simply and easily, or through various sorts of dream images. And so when much phlegm flows down, one dreams that he is being drenched by a huge amount of rain, or is almost being drowned in rivers and watery places. . . . When the black bile humor becomes dominant, one dreams of corpses, murders, woundings, snakes, tortures, afflictions, and every sorrowful thing. When the blood [dominates, one dreams of] weddings, dancing, banquets, laughter, and all happy things; but when yellow bile, quarrels, fires, conflagrations, flashes [of lightning].

Auguer Ferrier (1513-1588) was a French physician and astrologer who in his De diebus decretoriis secundum Pythagoricam doctrinam et astronomicam observationem (On critical days according to the teachings of Pythagoras and astronomical observation) (Leyden, 1549) cites ancient Greek medical writers like

1601). Haydock writes that people with yellow bile are afflicted with dreams of fire while those with phlegm with visions of snow, waters, and rivers. See also Marr (2017, pp. 113-181).

${ }^{37}$ I see the Roterdam 1649 edition of Tractus philosophici, quod nihil scitur. Brief mention of Sanches's theories are given in Siraisi (2015, p. 190). 
Galen to argue that some dreams are humorally based. Ferrier even discusses (pp. 134-136) reproduces the same dreams and their interpretations which Galen discusses in his treatise On Medical Diagnosis through Dreams. ${ }^{38}$ Ferrier then describes Hippocrates' and Galen's use of dreams to explain excesses of humors in a patient's body; for example those who suffer from an abundance of phlegm will see images of snow, ice, and hail (see further De Smet 1999, pp. 351-376).

I am not claiming that Browne was aware of the works of Cardano, Sanches, Ferrier, and others, although he may have given the library that he inherited from his father. ${ }^{39}$ What I am saying is that the idea that dreams can help to understand through dreams a person's bodily condition, state of humors, and type of illness was pervasive and generally accepted across Europe and England. ${ }^{40}$ There were of course skeptics, just as there were in antiquity (Harris 2009, pp. 83-90), but the resistance was directed mainly toward the supernatural dream (epiphanies, demonsent visions, etc.) and was due to the aversion to popular oneirology (Rivière 2003, 112-137). Natural dreams with a physiological basis were an accepted concept grounded in ancient medical and philosophical theory (Aristotle, Galen, Hippocrates) and were acknowledged as useful in diagnosing illness. ${ }^{41}$

\section{Conclusion}

My conclusion may strike the reader as unusual, for I intend to raise more questions than to answer them. First off, Browne was pursuing a degree in medicine and was defending his thesis before faculty and students of the medical school of Cambridge. And yet Browne disparages physicians who read Galen and Hippocrates. Browne begins this thesis with these words:

Why do you wander through the writings of physicians with tired vision?

Why do you study the doctrines of the old man of Cos [= Hippocrates]?

What usefulness [is there] when the lamp, late at night,

Watches you turning [the pages of] Galen of old? ${ }^{42}$

\footnotetext{
${ }^{38}$ Ferrier published in the same year Liber de Somniis (Lyon: Joannes Tornaesium, 1549), which contained Hippocrates' De insomniis translated by JC Scaliger; Galen's De insomniis translated by Joannes Guinterius Andernacus; and Synesius's De somniis translated by Marsilio Ficino.

${ }^{39}$ For sake of space I have limited this survey of dreams in continental European thought to these writers, as a fuller study would require a book-length treatment. Such a study would discuss René Descartes, for example; for an introduction to Cartesian dream thought, see Browne 1977, pp. 256-273, and Robert 2008, pp. 691-709; for application of Descartes' theories to explain psychological disorders, see López-Muñoz and Alamo 2011, pp. 449-451.

${ }^{40}$ This is a continuation of the medieval tradition (Fattori 1985, pp. 86-109).

${ }^{41}$ Ancient Greek dream theory is now used in modern psychotherapy. Edward Tick, for example, employs through organized pilgrimages to Greece dreams and dreaming for guidance and therapy; he connects ancient spiritual sites and mythology while focusing on dreams in order to effect physical, psychological, and spiritual healing among the participants. See Tick (2001); cf. Giannini 2004, pp. 75-91. A good review is Dubisch (2021).

${ }^{42}$ Note the epithet of "old" for both Hippocrates and Galen. The words senex and antiquus are ambivalent: in Latin, there is both a meaning of 'austere' and yet also 'old-fashioned.'
} 
An ill person, Browne continues, is his own best doctor. If someone is lying ill in his bed, he need only to pay attention to the images of his dream in order to self-diagnose. No need to call a diplomate physician when the ill can determine that, for example, "vitreous bile" is in excess and thus racking him with fever and inflammation. ${ }^{43}$ The next step for this person, armed with this knowledge, is not given in the text. Does he go to an apothecary or herbalist and ask for a drug on the basis of this self-diagnosis? Moreover, if a patient is a "second Hippocrates unto himself," 44 does that mean that Hippocrates is needed as well, or that he will be his own Hippocrates and thus is free to self-diagnose and seek out a medical cure? Is Browne verifying the role of the credentialed doctor, or is he coyly undermining the very religious establishment to which he belonged?

An answer to these questions may be found in the wonderfully ambiguous final lines, in the "ergo" conclusion. Here are the lines again.

Artemidore tuas Medicus pervolvere chartas

Difcat, \& ufque tuum dextra fatiget opus;

Unus fic meritò viciffe Machaonas omnes,

Parcarum \& poterit fiftere fila trium,

Flectere fic folitum curfum irremeabilis undae;

Denique Onirocrites, fic erit Hippocrates.

May the physician, Artemidorus, learn to turn over your pages

And may his right hand ever wear out your work;

In this way he alone will deservedly have surpassed all the practitioners of the Machaonian craft,

And be able to arrest the threads of life spun by the three sisters

And thus turn the usual course of the stream from which one cannot return.

In a word, the dream interpreter will thus be Hippocrates.

Why does Browne highlight Artemidorus, who was acknowledged as the most important popular dream interpreter of antiquity from the Middle Ages through Browne's lifetime? ${ }^{45}$ Although dream interpreters were generally considered quacks and charlatans at this time, Artemidorus was deemed a learned

\footnotetext{
${ }^{43}$ This does sound like Cardano and his praxis. But a better parallel may be Synesius of Syrene, who wrote his On Dreams before his conversion to Christianity in the third century. Synesius argued that every dreamer has a unique and individual dream language, and so recommended that every person to keep a daily journal of all his dreams and how they turned out in order to gain an empirical understanding of his own particular dream language. See Monticini (2017). Could Browne be advocating that a person look to his own dreams for his peculiar dream language in order to learn how his body worked and how its afflictions could be treated?

${ }^{44}$ Line 15: "Sibi Hippocrates . . alter erit."

${ }^{45}$ Artemidorus's Greek text was first known in England only in Latin but by 1606 it was translated into English and then reprinted numerous times throughout the seventeenth century; see Rivière (2001, p. 18). The dreambook became popular; even Browne's own father, Sir Thomas Browne, quoted from it in his treatise On Dreams. Sir Thomas divided dreams into divine (angelic) and animal dreams (dreams based on the thoughts and actions of the day). He believed that dreams were a means to self-knowledge, that is, what we dream is related to who we are. The treatise On Dreams (London: De La More Press, 1920) is only 14 pages in length. For brief discussion see, Fudge (2007, p. 38); fuller treatment in Levin (2008, pp. 47-50).
} 
scholar. $^{46}$ But, why does Browne hold up Artemidorus here? Why not Galen? Hippocrates? Aristotle? These giants are apparently dismissed in favor of Artemidorus. $^{47}$

I have no definitive answer for why Browne extols Artemidorus and his interpretative skills to the point that he is a better healer than trained medical practitioners. If we read the text literally, Browne is arguing that a diplomate doctor can benefit from Artemidorus in recognizing the value of learning a patient's dreams and examining the dream's images for possible hints to excess or lack of humors. Of course, this is not wholly problematical; since Artemidorus discussed medical dreams and advocated his own son to learn the medical art, he was deemed sympathetic to the healing profession. ${ }^{48}$ But why could Browne not name, in his concluding statement, Hippocrates and Galen who actually wrote treatises on humors and medical dreams? Browne had borrowed from these revered physicians throughout his thesis, but in the end he holds up Artemidorus as the authoritative expert. We know this because oneirokrites is the Latin transliteration of the Greek word óveıрокрítns ("interpreter of dreams") which Artemidorus applied to himself and was preserved in translations of Artemidorus's work. ${ }^{49}$ The proposition for Browne's thesis was Judicium de somniis est Medico utile ("A determination [of illness] based on dreams is useful for a physician"). It was not "A determination [of illness] based on Artemidorus's dream interpretation is useful for a physician." And yet the text appears to say that someone armed with Artemidorus's book on dream interpretation can surpass a doctor (Denique Onirocrites, fic erit Hippocrates).

There is, though, a way out of this. The Latin grammar, thanks to the copulative est, can give us a wholly different translation: "In a word, Hippocrates [that is, the doctor] will thus be a dream interpreter [Artemidorus]." What Browne is calling for is a holistic approach to the medical art. The physician must be like Machaon and be knowledgeable in surgery, formal medicine, pharmacology, and herbalism. But the physician must "surpass" (viciffe) these skills and take into account the dream theories of someone like Artemidorus who had made his profession an empirical science. Browne is not advocating for the doctor to incorporate into his practice the works of popular dream interpreters like Thomas Hill (Hill 1567), but for the principles of the magisterial dreambook of

\footnotetext{
${ }^{46}$ Very useful discussion in Rivière (2013, pp. 1-5); a fuller and thorough treatment in her chapter 2 (2017, pp. 50-88). Crawford (2000, p. 132) writes that Artemidorus's book was reprinted in English 24 times before 1724. Siraisi (2015, pp. 177-178) discusses the place of Artemidorus among the humanists and early renaissance. Also Levin, pp. 34-35.

${ }^{47}$ Browne dismisses them with the statement that Artemidorus "will deservedly have surpassed all the practitioners of the Machaonian craft." Machaon was an ancient physician mentioned in Homer's Iliad and was famous for healing and cures. In Iliad 2.273 his skill is mentioned; his knowledge of herbs is referred to in Iliad 4.219. Machaon's brother was Asclepius, who later became the god in charge of healing sanctuaries throughout the Mediterranean. The phrase "Machaonian craft," I would argue, is inclusive of all modes of medicine: surgeon, herbalist, doctor, and religious medical practitioners.

${ }^{48}$ Artemidorus's discussion of medical dreams, I acknowledge, is very brief and is more concerned with healing dreams at religious sanctuaries and quacks; see Oberhelman (1981, pp. 416-424).

${ }^{49}$ The latest edition of Artemidorus is Harris-McCoy (2012). Other editions are mentioned in Oberhelman (2014, pp. 96-98).
} 
Artemidorus. Granted, Artemidorus did not discuss dreams from a humoral perspective, but that is not the point. By referencing Artemidorus, Browne is telling the physician to examine dreams critically and to listen to his patient. Artemidorus argued that an interpreter of dreams had to rely on his powers of observation (têrēsis) and on his experiential knowledge (peira) of a sufficient number of dreams and their outcomes. ${ }^{50} \mathrm{He}$ stated clearly that absolutely crucial to any interpretation, is an interpreter's knowledge of a consultant's life and habits, since the images in a dream must be compared to the dreamer's biographical data: gender, number of children, marital status, social position, economic means, and so forth. And so, since a dream's meaning is dependent on the interpreter knowing the circumstances of each consultant, he must question the dreamer about his or her life and then decode the dream's significance based on those answers. This face-to-face session where a consultant tells the interpreter her or his life story, relates the concerns, anxieties, the hopes, and the fears in her or his life, is the precursor of a psychiatrist session. Even more, it is the precursor of today's discipline of narrative medicine, where the doctor learns to listen to the stories that a patient tells and learns how to draw out and understand those stories. ${ }^{51}$ I would argue that Browne is telling the doctors and soon-to-be doctors in his audience to be a more holistic caregiver - to be like Artemidorus and listen to their patients' stories. Hear their dreams, care about what they are experiencing, and interpret and then act upon those stories. ${ }^{52}$

\section{References}

Allen P (1946) Medical education in $17^{\text {th }}$ century England. Journal of the History of Medicine and Allied Sciences 1(1): 115-143.

Anderson M (2004) Physician heal Thyself: medical practitioners of eighteenth-century New York. New York: Pete Lang.

Browne A (1977) Descartes's dreams. Journal of the Warburg and Courtauld Institutes 40: 256-273.

Charon R (2006) Narrative medicine: honoring the stories of illness. New York: Oxford University Press.

Charon R (2011) Narrative medicine. In R Charon, S DasGupt (eds.), Literature and Medicine. Special Issue of Literature and Medicine 29(2): vii-xiii.

\footnotetext{
${ }^{50}$ The interpreter's first task, Artemidorus wrote, is to analyze the dream through six stoicheia (elements of analysis): nature, convention, habit, occupation, name, and time; the interpreter must then determine whether the dream is kata ("in accordance with"), or para ("in opposition to"), each of those elements. The two principle stoicheia, however, are phusis ("nature") and nomos ("convention"), with the latter category subdivided into unwritten social rules (ethē) and written laws (nomoi). Thus, for example, a dream that is kata phusin ("in accordance with nature") foretells something good, while a dream para phusin ("contrary to nature") signifies something evil.

${ }^{51}$ Good starting points for narrative medicine are Charon et al. (2017), Charon (2015), Charon (2011) and Charon (2006).

${ }^{52} \mathrm{I}$ would like to express my thanks of appreciation to the referees and the editors for improving this paper considerably. I am grateful to the librarian staff of the British Library and the American School of Classical Studies in Athens, where I researched and wrote this paper as a visiting senior scholar.
} 
Charon R (2015) Narrative medicine: the essential role of stories in medical education and communication. In IFernandes, C Beecher Martins, A Reis, Z Sanches (eds.), Creative dialogues. Cambridge: Cambridge Scholars Publishing.

Charon R, DasGupta S, Hermann N, Irvine C, Marcus ER, Rivera Colón E, et al. (2017) The principles and practice of narrative medicine. Oxford: Oxford University Press.

Costello W (1958) The scholastic curriculum at early seventeenth-century Cambridge. Cambridge, Mass.: Harvard University Press.

Crawford P (2000) Women's dreams in early modern England. History Workshop Journal 49: 129-141.

De Smet I (1999) Of doctors, dreamers and soothsayers: the interlinking worlds of Julius Caesar Scaliger and Auger Ferrier. Bibliothèque d'Humanisme et Renaissance 70(2): 351-376.

Dubisch J (2021) Pilgrimage for a new age: ancient sites, new meanings. London: Taylor $\&$ Francis.

Evans GR (2009) The University of Cambridge: a new history. London: I. B. Tauris.

Fattori M (1985) Sogni e temperamenti (Dreams and temperaments). In T Gregory (ed.), I Sogni nel Medioevo: Seminario Internazionale. Roma, 2-4 Ottobre 1983. Lessico Intellettuale Europeo, 35. Roma: Ateneo, 86-109.

Ferrier (1549) Liber de somniis (Book of dreams). Lyon: Joannes Tornaesium.

Finch J (1986) A catalogue of the libraries of Sir Thomas Browne and Dr. Edward Browne, His son - with introduction, notes and index. Leiden: Brill, 1986.

Fudge E (2007) Onely proper unto man: dreaming and being human in the renaissance. In Wiseman, Hodgkin, O'Callaghan, Reading the Early Modern Dream: The Terrors of the Night, 31-44.

Gallop D (1990) Aristotle on sleep and dreams: a text and translation with introduction, notes, and glossary. Petersborough, Ontario, and Lewiston, NY: Broadview Press.

Giannini J (2004) Pilgrimage to the ancient healing sites of Greece: a journey with Edward Tick. The San Francisco Jung Library Journal 23(1): 75-91.

Guidorizzi G (1973) L'opuscolo di Caleno 'De dignotione ex insomniis'. (Caleno's brochure 'De dignotione ex insomniis'). Bollettino per la Preparazione dell'edizione Nazionale dei Classici Greci e Latini 21: 81-105.

Harris WV (2009) Dreams and experience in classical antiquity. Cambridge, Mass, and London: Harvard University Press.

Harris-McCoy D (2012) Artemidorus' Oneirocritica: text, translation, and commentary. Oxford: Oxford University Press.

Haydock R (2008) Oneirologia, or, A briefe discourse of the nature of dreames: discoueringe howe farre the reasonable soule exerciseth her operations in the time of sleepe and prooueinge that in sleepe there can be no reasonable and methodical speech (1605). In C Levin, dreaming the English renaissance: politics and desire in court and culture. New York: Palgrave.

Hill T (1567) A little treatise of the interpretation of dreams, fathered on Joseph. London: William Copland.

Hodgkin K (2007) Dreaming meanings: some early modern dream thoughts. In S Wiseman, K Hodgkin, M O'Callaghan (eds.), Reading the Early Modern Dream: The Terrors of the Night. London and New York: Routledge.

Holowchak MA (2001) Ancient science and dreams. Oneirology in Greco-Roman antiquity. Lanham, MD: University Press of America.

Hulskamp MAA (2008) Sleep and dreams in ancient medical diagnosis and prognosis. Ph.D. Thesis. Newcastle, UK: University of Newcastle. 
Hulskamp MAA (2013) The value of dream diagnosis in the medical praxis of the Hippocratics and Galen. In Oberhelman SM (ed.), Dreams, Healing, and Medicine in Greece: From Antiquity to the Present, 33-68. Farnham: Ashgate.

Hulskamp MAA (2015) On regimen and the question of medical dreams in the Hippocratic corpus. In L Dean-Jones, RM Rosen (eds.), Ancient Concepts of the Hippocratic: Papers Presented at the XIII International Hippocrates Colloquium. Austin, Texas, August 2008. Studies in Ancient Medicine, 46. Leiden: Brill, 258-270.

Huntley FL (1962) Sir Thomas Browne: a biographical and critical study. Ann Arbor: University of Michigan Press.

Jouanna J, Allies N (2012) The legacy of the Hippocratic treatise The Nature of Man: the theory of the four humors. In P Van der Eijk (ed.), Greek Medicine from Hippocrates to Galen: Selected Papers. Leiden and Boston: Brill.

Levental D (1981) Edward Browne, 1642-1708. The Bart's Journal (summer): 22-29.

Levin C (2008) Dreaming the English renaissance. Palgrave Macmillan US.

López-Muñoz F, Alamo C (2011) Cartesian theories on the passions, the pineal gland and the pathogenesis of affective disorders: an early forerunner. Psychological Medicine 41(3): 449-451.

Marr AJ (2017) Richard Haydocke's Oneirologia: a manuscript treatise on sleep and dreams, including the 'Arguments' of King James I. Erudition and the Republic of Letters 2(2): 113-181.

Monticini F (2017) ... et l'âme créa le rêve: Le traité Sur les songes de Synésios de Cyrène. (... and the soul created the dream: the treatise on the dreams of Synesios of Cyrene). Byzantinische Zeitschrift 110(1): 69-88.

Nathanson L (1967) The strategy of truth: a study of Sir Thomas Browne. Chicago: University of Chicago Press.

Oberhelman SM (1981) The interpretation of prescriptive dreams in ancient Greek medicine. Journal of the History of Medicine 36(4): 416-424.

Oberhelman SM (1983) Galen, On Diagnosis from Dreams. Journal of the History of Medicine 38(1): 36-47.

Oberhelman SM (1993a) Introduction: medical pluralism, healing, and dreams in Greek culture. In Dreams, Healing, and Medicine in Greece, 1-33. Routledge.

Oberhelman SM (1993b) Dreams in Graeco-Roman medicine. In Aufstieg und Niedergang der römischen Welt. Berlin: Walter de Gruyter.

Oberhelman SM (2014) Review of Harris-McCoy Artemidorus' Classification of Dreams (D.E.) Harris-McCoy Artemidorus' Oneirocritica. Classical Review 64 (1): 96-98.

Patrides CA (Ed.) (1982) Approaches to Sir Thomas Browne. Columbia, MO: University of Missouri Press.

Post J (1987) Sir Thomas Browne. Boston: Twayne Publishers.

Rivière J (2001) 'Filthy Dreamers and Scurrilous Dreams': the politics of dreams in seventeenth-century England. Proceedings of the University of Queensland History Research Group 12(2001): 15-22.

Rivière J (2003) 'Visions of the Night': the reform of popular dream beliefs in early modern England. Parergon 20(1): 109-138.

Rivière J (2013) Dreams in early modern England: frameworks of interpretation. Ph.D. Thesis. Toronto, Canada: University of Toronto, 2013.

Rivière J (2017) Dreams in Early Modern England: "Visions of the Night". Oxon and New York: Routledge.

Robb-Smith HT (1974) Cambridge medicine. In AG Debus (ed.), Medicine in Seventeenth-Century England, 326-369. Berkeley and Los Angeles: University of California Press.

Robert (2008) Descartes' dreams. The Journal of Analytical Psychology 53(5): 691-709. 
Rook A (1963) Medical education and the English universities before 1800. Journal of Medical Education 38(8): 639-643.

Scioli E (2015) Dream, fantasy, and visual art in Roman Elegy. Wisconsin Studies in Classics. Madison: University of Wisconsin Press.

Scott R (2014) Dreams and the passions in revolutionary England. Ph.D. Thesis. Sheffield, UK: University of Sheffield.

Segev M (2012) The teleological significance of dreaming in Aristotle. Oxford Studies in Ancient Philosophy 43(Nov): 107-141.

Shaw AB (1978) Sir Thomas Browne: the man and the physician. Annals of the Royal College of Surgeons of England 60(4): 336-344.

Siraisi N (1990) Medieval and early renaissance medicine: an introduction to knowledge and practice. Chicago: University of Chicago Press.

Siraisi NG (2015) The clock and the mirror: Girolamo Cardano and renaissance medicine. Princeton: Princeton University Press.

Stelmack RM, Stalikas A (1991) Galen and the humour theory of temperament. Personality and Individual Differences 12(3): 255-263.

Tick (2001) The practice of dream healing: bringing ancient Greek mysteries into modern medicine. Wheaton, IL.

Tryon T (1691) Pythagoras his mystick philosophy reviv'd; or the mystery of dreams Vnfolded. London: Tho. Salusbury.

Twigg J (1990) The University of Cambridge and the English revolution, 1625-1688. Rochester, NY: Boydell \& Brewer.

Van der Eijk P (1995) Aristotle on 'distinguished physicians' and on the medical significance of dreams. Clio Medica 28: 447-459.

Van der Eijk PJ (2004) Divination, prognosis and prophylaxis: the Hippocratic work 'on dreams' (De Victu 4) and its near eastern background. In HFJ Hostmanshoff, M Stol (eds.), Magic and Rationality in Ancient Near Eastern and Graeco-Roman Medicine, 187-218. Leiden: Brill.

Van Strien K (2004) Browne, Edward (1644-1708). In Oxford Dictionary of National Biography. Oxford: Oxford University Press.

Wiseman S, Hodgkin K, O'Callaghan M (2014) Introduction. In Reading the Early Modern Dream: The Terrors of the Night. London and New York: Routledge. 